\title{
HUMAN DEVELOPMENT AND WOMEN EMPLOYMENT IN UZBEKISTAN: SITUATION AND PROBLEMS
}

\author{
SHOIRAKHON NURDINOVA ${ }^{1}$ \\ Tashkent State Technical University (Uzbekistan)
}

\begin{abstract}
The role of human development concept has significantly changed recently. The relationship between women's employment and human development has been studied by many specialists. The aim of this paper is to discuss links between women employment and human development in Uzbekistan. The case study was based on analyses of labour market. The paper focuses on the human development of Uzbekistan from the year 1991 to 2011.The paper has been prepared by structuring and generalizing the content of studies carried out by different scientists and specialists, by deteriorating of documents to statistical data analysis and literature review. KEY WORDS: human development, women employment, Uzbekistan.
\end{abstract}

JEL CODES: O15, J71, O53

DOI: http://dx.doi.org/10.15181/rfds.v13i2.827

\section{Introduction}

Most economists have vested interest in women studies and its connection with various phenomena in the different fields of science. Not only economists have immersed interest in it but also socialists, lawyers and scientists with related fields in education, law, development etc. Pakistani scientist Mahbub ul-Haq offers human development conception as holistic development concept, embracing both the means, the productive capacity and the equity; both the economic and the social development; both the material wealth and the social services (Mahbub ul-Haq, 1996). Since its launch in 1990, the global Human Development Report has created and developed three human development index compound measures various aspects of human development: the human poverty index, the gender-related development index and the gender empowerment measure. According to international measurement, the main indicator of Human development index is Gender Inequality. Inequality exists when there is a difference in the distribution of a resource (such as income) or outcome (such as morality or educational achievement) across groups of peoples and places. Any choice of inequality indicator involves implicit choices about which dimensions of inequality are important to capture (Shaw M. \& et al, 2007).

The article contains literature overview on human development, women employment and their relationship. Gender issues and women unemployment includes opportunities in the labour market, division of labour at home, deteriorating health indicators and gender-based violence. The research was based on statistical data analysis. Data were collected from Statistical Committee of Uzbekistan and the reports of international organizations. The object of the paper is labour market and women's status Uzbekistan. The measure of Human Development Index of the United Nations for Uzbekistan was used in this study. The

Shoirakhon Nurdinova - doctoral student, Tashkent State Technical University, Faculty of Management at industrial sectors Scientific interests: Economic Theory, Sustainable Development and Gender Studies.

E-mail: sh.nurdinova@gmail.com 
tasks of the research:

- to evaluate the scientific literature, normative acts and documentation that related to gender aspects of human development;

- to determine the main problems and perspectives of women employment;

- to provide recommendations for sustainability of the women employment.

In order to achieve goal the author uses a theoretical analysis of the scientific literature, analytical methods, and comparative method.

\section{Socio-economic development and the Millennium Development Goals in Uzbekistan}

In Uzbekistan, the human development is starting to find its way into the social life of the people. The Government of Uzbekistan aims to solve the challenges outlined in the Millennium Development Goals (MDGs). The Human Development Report of Uzbekistan was published since the year 1996 and the preceding challenges, problems, opportunities and perspectives described the fundamental knowledge to gain understanding of sustainable human development and national MDG goals (UNDP in Tashkent, 1996).

The national MDG goals are given in following:

1. Improve living standards and reduce malnutrition.

2. Improve the quality of primary and general secondary education while maintaining universal access.

3. Promote gender equality and empower women.

4. Reduce child mortality.

5. Improve maternal health.

6. Combat HIV/AIDS, tuberculosis, and malaria.

7. Ensure environmental sustainability.

8. Uzbekistan and Global Partnership for Development (Доклад по Целям Развития Тысячелетия в Узбекистане, 2006: 8).

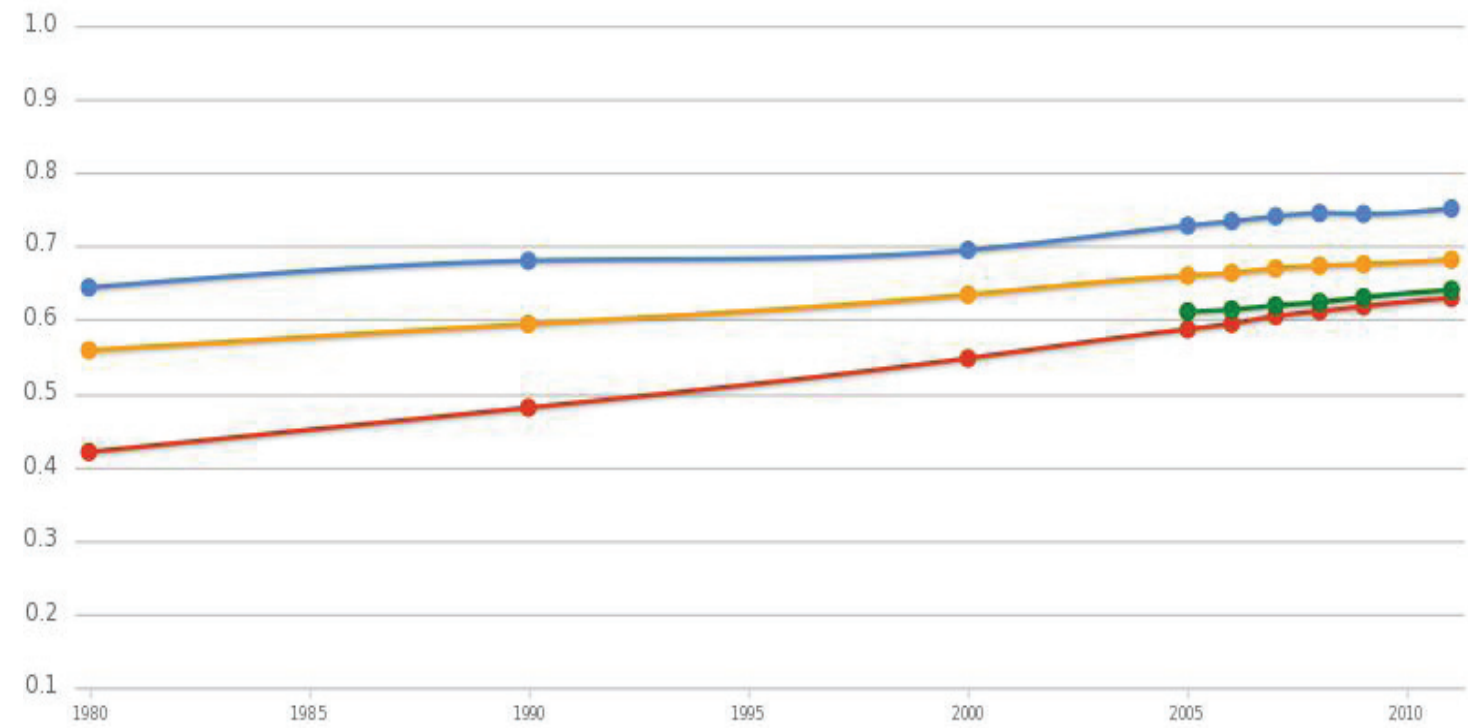

Europe and Central Asia

Medium human development

World

Uzbekistan

Figure 1. Human development index tendency in Uzbekistan

Source: developed by the author from the data of Human Development Reports, 2011 
In 2010, the United Nations (UN) General Assembly organized some branches as UN Women, the United Nations Entity for Gender Equality and the Empowerment of Women. Thereby, UN Member States put a historic step in accelerating the Organization's goals on gender equality and the empowerment of women. The United Nations Millennium Development Goals and associated target are to eliminate gender disparity in primary and secondary education, and in all levels of education by 2015 (Nurdinova, 2013: 460).

In this regard, Cabinet of Ministers of Uzbekistan accepted judgment about "Additional measures on the Millennium Development Goals United Nations in Uzbekistan". Legal, social and economic programmes are supported by the government helps to increase the Human Development Index in Uzbekistan.

In Figure 1 points describe certain development level in Uzbekistan by Human Development Index. The "2010" point is located mainly below respective " 2005 " point. It points that Human Development Index in Uzbekistan has increased at the last 20 years. As well as we can see that Human Development Index in Uzbekistan is 0.641 and country's ranking with medium Human Development is 115 among 187 countries all over the world. Social-oriented state programs and long-term changes in education, health care and social protection system strengthens to gain sustainable development in Uzbekistan. According to M. Kamp, "Gender" seems to have entered Central Asia as a term used in development programs. The United Nations had been using the "Gender in Development" paradigm to analyze socioeconomic situations in Third World countries, in order to direct attention to changes that will benefit women, such as increasing education for girls and providing lending programs so that women can enhance livelihoods (Kamp, 2009). It must be noted, that the above is true, the term "gender" is less familiar to society as the category and it encourage women's status in many cases. Therefore, the Constitution and laws of the Republic of Uzbekistan contains provisions for further improving women's status in society, ensuring their rights and interests, and to provide them with decent working environment.

Women's Committee with the involvement of non-governmental organizations actively takes part in the preparation of national reports on the implementation of commitments made by the country in the field of women's rights. In 1995, Uzbekistan ratified the Convention on the Elimination of All Forms of Discrimination against Women (CEDAW) (Welfare Improvement Strategy Paper, 2007: 58). Also, decree of the President of Uzbekistan "On strengthening the role of women in state and social construction" was accepted in 1995. Furthermore annually with further accepting government programs aimed at developing and promoting the role and interests of women and children: Year of the Family, Women's Year, the Year of Mother and Child, Year healthy generation and other.

\section{Women and labour market}

Labour market is a concept for interaction between employers and employees in the market economy. While reviewing the literature about labour market, we can identify that each of the three variants of female employment means different relationship between the professional and the family and domestic sphere. The first option is the priority of the "work" of professional duties, priority of "home", or family responsibilities. This option is the most effective combination of the two spheres of life, the two spheres of employment, "work" and "home".

Option-employed in social production has a number of benefits for women, and for society as a whole. Gradually, it will become the main, dominant version of women's employment. In many developing countries the proportion of working women in the informal economy represents a larger source of employment for women than formal employment (ILO, 2009).

Employment of citizens in the economically active population (in accordance with the Law of Employment of the Republic of Uzbekistan) includes persons of both men and women aged 16 years and older, and those younger than 16 years old, who in the reference period:

- Perform work for hire for a fee on a full or part-time, as well as, other gainful employment.

- Temporarily absent from work due to illness, vacation, holidays, strikes or other similar reasons.

- Undertake payless job in a family enterprise. 
Women is playing important role to eradicate poverty and human development process. Various antipoverty and employment programmes / schemes are generated by central and state Government. And these are targeted to those women who are ready to work but remain unemployed for lack of employment opportunity (Kalpana, Mohan, 2012: 33). Socio-economic characteristics of women's employment and the presence of female unemployment will require development and implementation of specialized tools to regulate employment for women. Tools to regulate employment for women must meet the following requirements: 1) focus on specific groups of women; 2) coordination of interests of the employee (women), the employer and the state (society) and 3) the right of women to freely choose the right option for her employment.

Men were seen as the main breadwinners, and they did not in general take on an equal share of household responsibilities. Women were given primary responsibility for nurturing the family. As a result, women performed paid work in the labor market, and did long hours of unpaid work at home. The fact that the predominant share of unpaid work was taken on by women, and the fact that women had to combine employment with child care responsibilities, contributed to the labor market segregation described above (ADB report, 2005: 5).

Discrimination against women in employment is also frequent outside the agricultural sector, and has an impact on the kinds of work, careers and career advancement that women can expect. The gap between participation rates of women and men has narrowed slightly in the last 20 years but remains considerable (UN report, 2010: 27).

Labour supply means the total amount of labour, characterized the size and composition (gender, age, education, occupation, qualifications, etc.). The education influences to labour supply and labour price.

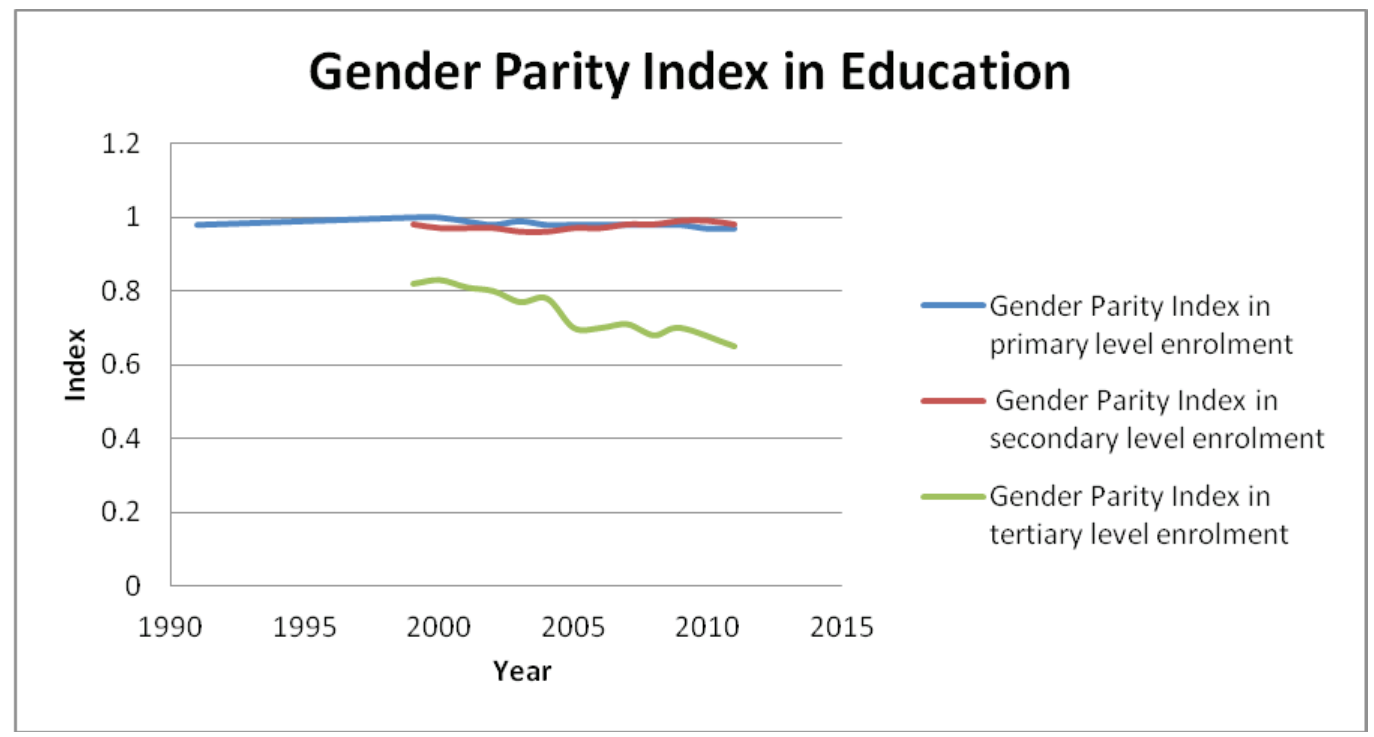

Figure 2. Gender differences in education system

Source: developed by the author from the data of Human Development Reports, 2011

According to the constitution of Uzbekistan and the law for Education, primary and secondary educations are free. Every citizen must graduate with a 12-years education: school and academic lyceum / professional college. So it is easy to see in Figure 2 gender parity index in primary and secondary level enrollment is close to 1 , its means that the number of total female students and number of total male students is equal in education. But an "enrollment in higher education" point shows that girls and women are disadvantaged in this level of education and the situation has hardly improved in the last five years.

That is worth mentioning which individual development as getting a job or social enforcement and its growing in cultural problems, all of them are resulting of investment over educational systems. Therefore, based upon human development factor which can be based for measurement of human abilities, designs of 
educational skillfulness in complementary educations must be considered, at least government must pay attention to girls in higher education system for enhancing its economical section (Yousefy, Baratali, 2011).

As shown in Figure 2 gender parity index in tertiary level enrolment is decreasing year by year. Consequently majority of female students get married during study period. According to the statistical data of OSCE in Uzbekistan, the number of married female students in education institutions is described in table 1.

Table 1 . The number of married female students in education institutions

\begin{tabular}{|l|l|l|}
\hline \multicolumn{1}{|c|}{ Marriages } & \multicolumn{1}{c|}{ Female } & \multicolumn{1}{c|}{ Male } \\
\hline All marriages & 208487 & 208487 \\
\hline With higher education diploma & 9192 & 17855 \\
\hline Students in higher education institutions & 4928 & 4349 \\
\hline With college diploma & 37295 & 29588 \\
\hline College students & 2030 & 1667 \\
\hline With a high school certificate & 154993 & 154937 \\
\hline With a primary education or below & 48 & 85 \\
\hline No information about education & 1 & 6 \\
\hline
\end{tabular}

Source: developed by the author from the data of OSCE in Uzbekistan, 2006

The value of labor power is determined by the social costs of its reproduction, that is, volume use of tangible and intangible benefits. We know that jobs are mostly divided into gender "male" and "female" and that the work traditionally performed by women, are paid less than those that are usually done by men.

It is also true that most of the "women's" jobs are paid less than those that are predominantly men, even if this work will require a very serious preparation. Among scientists, like Sh. Burn, examining labour market as sectors dominated by women and men for analysis salaries concluded that workers in sectors dominated by women earn less than those who work in predominantly "male" jobs (Burn, 1995).

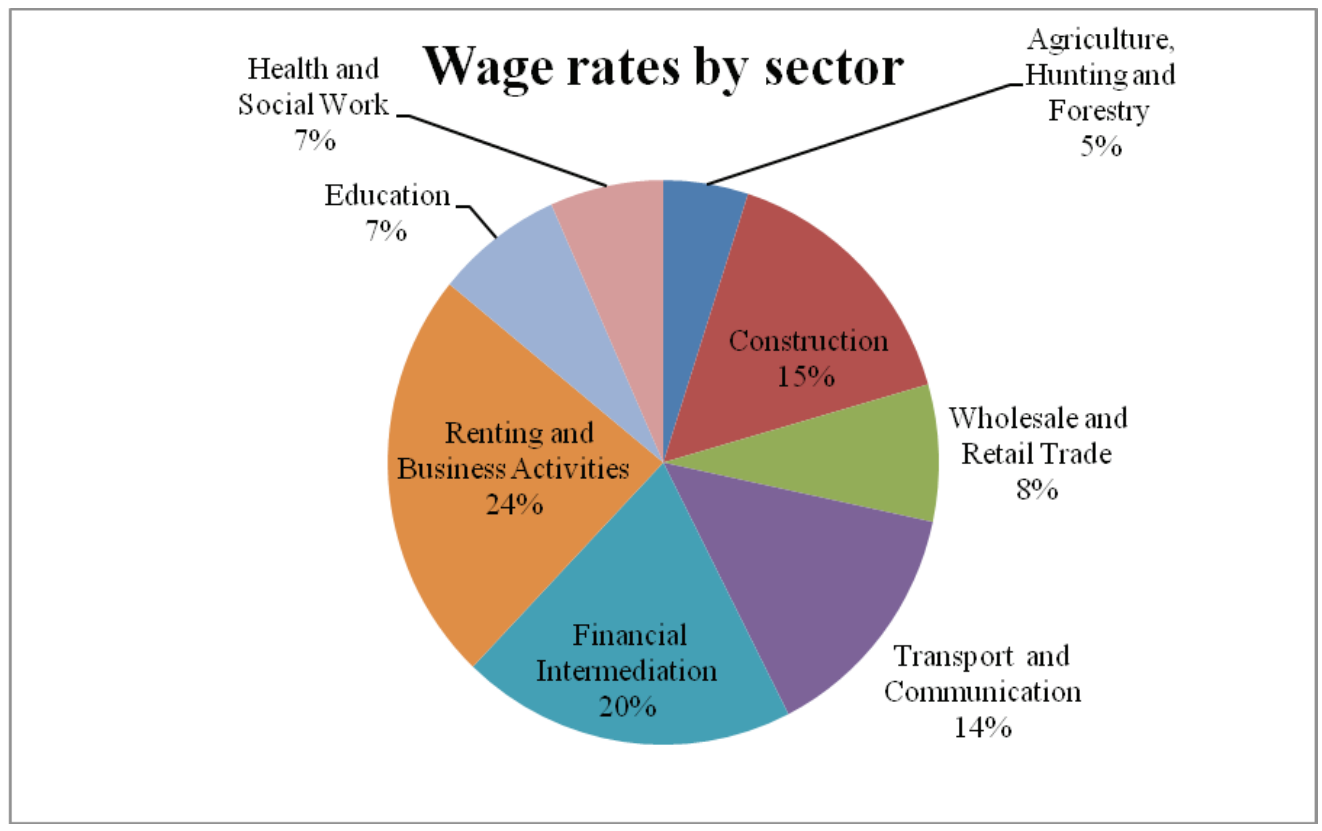

Figure 3. Payment for labour market in economic sectors

Source: developed by the author from the data of International Labour Organization, 2011

Economic sectors of labour market in Uzbekistan presented in Figure 3. The point is that wages are higher on the sectors and "male" jobs. 
As an economic concept, the labour market reflects the relationship between the owners of this product (employee), who is also the sellers and buyers (employers). In view of the specificity and importance to society of the relationship they are made legally in the labour laws.

The subject of regulation of labour law and labour relations are working under an employment contract, as state-owned enterprises, and based on other forms of property, including individuals. Except for labour relations in the implementation of the right person to work there, and others connected with them, which are also regulated by the law.

Along with the individual employment relationship, a number of collective relations, which are also regulated by law.

Notice of an employee may be granted leave without pay for the duration of which is determined by an agreement between him and the employer. At the request of the woman or the persons mentioned in the third part of this article, at the time they are on leave for child care they can work part-time or by agreement with the employer at home. At the same time they retain the right to receive the benefits (the first part of this article.)

During the period of maternity leave woman saves her job (position) and these holidays are counted in the length of service, but the leave should not more than three years in total, including professional experience (Article 234).

The right of women with children under three years of age and working in institutions and organizations financed from the budget, shorter hours of work

Women with children under three years of age and working in institutions and organizations financed from the budget, working is set at thirty-five hours a week.

Payment of women mentioned in part one of these articles, the reduction of working time is the same amount as for the corresponding categories of employees in full working day (Article 228-1).

Refusal to hire women in an employment and reduction of their salaries on the grounds that they are expecting or have children. When refusing to hire a pregnant woman or with a child under the age of three years, the employer must inform them of the reasons for refusal in writing. Refusal to employ such persons may be challenged in court (Article 224).

The employment of women in jobs with poor working conditions, as well as the underground work, except for some underground work (non-physical work or work with health and consumer services).

Female gender because of tradition, mostly employed in "female" dominated jobs for which pay less than traditionally "male" environment. Explanation on the basis of compensating differences suggests that women choose low-paid jobs in return better working conditions: a good social climate, the ability to help others, more flexible and easier work (Filer, 1985, 1989).

The labour force is divided by gender. Most professions are mainly dominated by one or opposite gender.

Women are in fact rarely do jobs traditionally belongs to men, it is also true that the wages for "women's" work below. According to statistics, it is not so. "Women's" work does not imply more flexible, lower levels, or anything else that would help parenting. In fact, according to (Glass, Camarigg, 1992: 151), the opposite is true: a large concentration of women in a professional field is associated with less flexibility, more control by superiors and less freedom in determining the methods and timing of tasks (Burn, 1995).

All in all, we can conclude that it is really important to ensure to create equal opportunities for both men and women in labour market.

In the table 2 we can see job distribution in economic sectors by gender, and according to the data we can say that during the period 2000-2007 savings-investment spending identities were hold. It means that identity total income equals total investment is true, and savings and investment spending are interacted empirically. 
Table 2. Employees in the sectors of economy by gender

\begin{tabular}{|c|l|l|l|}
\hline \multicolumn{1}{|c|}{ Sector } & Employee (women) \% & Employee (men) \% \\
\hline 1. & Industry & 42 & 58 \\
\hline 2. & Forestry and agriculture & 51.1 & 48.9 \\
\hline 3. & Construction & 12.8 & 87.2 \\
\hline 4. & Transportation and communication & 17.3 & 82.7 \\
\hline 5. & Trade & 53.7 & 46.3 \\
\hline 6. & Health, sports, social welfare & 78.3 & 21.7 \\
\hline 7. & Education, culture, science & 68.7 & 31.3 \\
\hline 8. & Finance, credit, insuranse & 45.5 & 54.5 \\
\hline
\end{tabular}

Source: Women and Men in Uzbekistan, Statistical Bulletin, 2000-2007, OSCE, Tashkent, 2010

\section{Women with disabled children}

According Labour Code of the Republic of Uzbekistan, woman with a disabled child under the age of 16 years can get an extra day-off per month; employer should provide her keeping the average daily wage.

Women, who have a disabled child under the age of 16 years, annually granted additional paid leave (three working days) and if they wish, they can leave without pay (not less than fourteen days). The data of additional leave may be attached to a main holiday, and provided individually or in parts.

If you are a single parent, while granting of leaves should be agreed in advance with the administration.

Labour law provides for reduced working hours for women, having a disabled child under the age of 16 years. This privilege is not provided for men.

Duration of the reduced working hours (part-time) can be inverted to workers and law is not limited to any size. Transition to part-time work does not cause the employee to limit the length of annual leave and paid in proportion to the time worked.

The scientific research allowed exploring women employment and human development in Uzbekistan: its status, challenges and opportunities of development in the context of international experience.

\section{Conclusions}

Women employment and gender equality are the integral element of sustainable human development without which the state cannot harmoniously develop. The major role of gender equality consists in maintenance with a significant amount of women in policy-making, women in education and labour market.

Gender equality can bring the considerable contribution to the decision of problems of economic growth and employment. In the conditions of market economy they are considered effective from the point of view of development. Uzbekistan completely to realize the potential of women employment, however in practice women face number of barriers which are not allowing them to effectively develop, being involved in and influencing their position in labour market.

For improving women employment in Uzbekistan it is necessary to eliminate the factors encouraging by the state support. Nowadays there are still varieties of possibilities that women employment has considerably increased. Still there are questions demanding steadfast attention such as, rural women unemployment, re-education of women after giving birth to babies, pregnant women working conditions. And nevertheless, there are hopes that the government will undertake the further steps on the way of improvement of women employment, the human development in Republic considerably will improve also gender equality index.

\section{References}

Asian Development Bank (ADB). (2005). Country Gender Assessment Uzbekistan. Philippines: ADB. Bum, Sh. M. (1995). The Social Psychology of Gender. McGraw-Hill College. 
Donald, R. W. (2012). Gender discrimination and self-employment dynamics in Europe. The Journal of Socio-Economics, Vol. 41.

Glass, J., Camarigg, V. (1992). Gender, parenthood, and job-family compatibility. USA.

Haq ul, M. (1996). Reflections on human development. Delhi: Oxford University Press.

Human Development report. (2011). UNDP Tashkent.

International Labour Office. (2009). Guidelines on Gender in Employment Policies, research paper. Geneva.

International Labour Office. (2010). Women in labour markets: measuring progress and identifying challenges. Geneva.

Kalpana, S., Mohan, P. (2012). Mainstreaming Women Employment and Human Development in Kheda District India. Sustainable Livelihood Approach to Poverty by UNDP.

Kamp, M. (2009). Women's Studies and Gender Studies in Central Asia: Are We Talking to One Another. Central Eurasian studies Review.

Labour Code of Uzbekistan. Tashkent.

Nurdinova, Sh. (2013). Human Development and Gender Issues: a case of Uzbekistan and Latvia. Riga: New Challenges of Economic and Business Development.

Shaw, M., Bruna, G., Debbie, A., Lawlor, L. J., Wheeler, B., Davey, S. G. (2007). The Handbook of inequality and socioeconomic position: concepts and measures.

Statistical Bulletin, 2000-2007. (2010). Women and Men in Uzbekistan. OSCE, Tashkent.

Tansykbaev, G. M., Kurganovskaya, N. I. (2008). Guide for gender analysis of legislation. Tashkent.

UN. (2010). The world's women 1995: trends and statistics. New York.

UNDP in Uzbekistan. (1996). Relationships Between Economic Growth and Human Development. Tashkent.

UNDP in Uzbekistan. (2007). Labour Migration in Uzbekistan: Social, Legal and Gender Aspects. Tashkent.

UNDP Tashkent. (2006). Доклад по Целям Развития Тысячелетия в Узбекистане, Tashkent.

Welfare Improvement Strategy Paper. (2007). Tashkent.

Yousefy, A., Baratali, M. (2011). Women, Employment and Higher education schoolings. WCES-2011.

\section{ŽMOGIŠKIEJI IŠTEKLIAI IR MOTERŲ IDARBINIMAS UZBEKISTANE: SITUACIJA IR PROBLEMOS}

SHOIRAKHON NURDINOVA

Taškento valstybinis technikos universitetas (Uzbekistanas)

\section{Santrauka}

Pagrindinès šiame straipsnyje aprašytos problemos susijusios su moterų užimtumu ir situacija darbo rinkoje Uzbekistane. Tyrimo objektas - darbo rinka ir moterų padètis: moterų užimtumo ir žmogiškųų išteklių plètros problemos bei perspektyvos Uzbekistane. Tyrimu siekta ištirti moterų dalyvavimą darbo rinkoje ir žmogiškujjų išteklių raidą Uzbekistane. Ivvertinus problemas ir galimybes dirbti Uzbekistano moterims, pateikiamos šių galimybių perspektyvos. Tyrimo uždaviniai: įvertinti mokslinę literatūrą, norminius aktus ir dokumentus, kurie susiję su lyčių aspektu plètojant žmogiškuosius išteklius; nustatyti pagrindines moterų užimtumo problemas ir perspektyvas; pateikti rekomendacijų dẻl tvarios moterų užimtumo plètros. Atliekant tyrimą taikyti šie metodai: mokslinès literatūros, norminių aktų ir dokumentų, susijusių su moterų užimtumo plètra Uzbekistane, analizè ir sinteze, informacijos ir duomenų apie žmogiškųų išteklių raidą Uzbekistane ir jos pokyčius apibendrinimas, atsižvelgiant ị ekonomines ir socialines tendencijas. Be to, analizuoti duomenys iš Uzbekistano socialinès apsaugos ir darbo ministerijos, ịvairūs planavimo dokumentai bei ataskaitos apie ekonominę ir socialinę moterų užimtumo būklę skirtingais metais. Nustatyta, kad didžiausios užimtumą lemiančios problemos yra išsimokslinimas, profesinè kvalifikacija ir kt. Apibrež̌iamos šių pagrindinių veiklų perspektyvos: kelti užimtumo lygį, sudaryti galimybes kurti darbo vietas moterims, remti darbuotojas moteris, auginančias vaikus.

PAGRINDINIAI ŽODŽIAI: žmogiškuju ištekliu plètra, moteru užimtumas, Uzbekistanas.

JEL KLASIFIKACIJA: O15, J71, O53 